\title{
Purified cranberry proanthocyanidines (PAC-1A) cause pro- apoptotic signaling, ROS generation, cyclophosphamide retention and cytotoxicity in high-risk neuroblastoma cells
}

\author{
AJAY P. SINGH ${ }^{1,2}$, THILO S. LANGE ${ }^{3,4}$, KYU K. KIM $^{3}$, LAURENT BRARD ${ }^{5}$, TIMOTHY HORAN ${ }^{3}$, \\ RICHARD G. MOORE ${ }^{3}$, NICHOLI VORSA ${ }^{1,2}$ and RAKESH K. SINGH ${ }^{3}$
}

${ }^{1}$ Department of Plant Biology, Rutgers University, New Brunswick; ${ }^{2}$ Philip E. Marucci Center for Blueberry and Cranberry Research and Extension, Rutgers University, Chatsworth, NJ 08901; ${ }^{3}$ Molecular Therapeutics Laboratory,

Program in Women's Oncology, Department of Obstetrics and Gynecology, Women and Infants' Hospital, Alpert Medical School, Brown University, Providence, RI 02905; ${ }^{4}$ Department of Molecular Biology, Cell Biology, and Biochemistry, Brown University, Providence, RI 02912; ${ }^{5}$ Department of Obstetrics and Gynecology, SIU School of Medicine, P.O. Box 19640, Springfield, IL 62794-9640, USA

Received June 27, 2011; Accepted July 29, 2011

DOI: $10.3892 /$ ijo.2011.1225

\begin{abstract}
Optimized purification of oligomeric proanthocyanidines (PAC) from cranberry generated PAC-1A which selectively affected the viability of various neuroblastoma (NB) cell lines representing a spectrum of high-risk NB features. PAC-1A caused a loss of mitochondrial transmembrane depolarization potential $(\Delta \Psi \mathrm{m})$ and increased generation of reactive oxygen species (ROS) which was directly correlated to the modulation of apoptotic marker proteins in SMS-KCNR cells. PAC-1A reduced the expression of pro-survival (Bcl-2, MCL-1, Bcl-xL) and increased levels of pro-apoptotic (Bax, Bad, Bid) Bcl family proteins, upregulated the activity of SAPK/JNK MAPK and downregulated expression or activity of PI3K/AKT/mTOR pathway components. PAC-1A increased the cellular uptake/ retention of cyclophosphamide (CP). PAC-1A and CP synergistically increased cytotoxicity and expression of pro-apoptotic markers, reduced cellular glutathione (GSH) and superoxide
\end{abstract}

Correspondence to: Dr Rakesh K. Singh, Program in Women's Oncology, Department of Obstetrics and Gynecology, Women and Infants Hospital of RI, 101 Dudley Street, Providence, RI 02905, USA E-mail: rsingh@wihri.org

Professor Nicholi Vorsa, Department of Plant Biology, Rutgers University, New Brunswick, NJ 08901, USA

E-mail: vorsa@aesop.rutgers.edu

Abbreviations: NB, neuroblastoma; PAC, proanthocyanidin; ROS, reactive oxygen species; MAPK, mitogen-activated protein kinase; FACS, fluorescent-activated cell sorting; CDKs, cyclin-dependent kinases; TNF, tumor necrosis factor; GSH, glutathione; mTOR, mammalian target of rapamycin; TNF $\alpha$, tumor necrosis factor- $\alpha$; $\mathrm{CP}$, cyclophosphamide; SOD, superoxide dismutase

Key words: cranberry, proanthocynidine, apoptosis, cell cycle, cyclophosphamide, TNF $\alpha$ dismutase (SOD) levels. Additional features of PAC-1A as an anticancer drug as shown in SMS-KCNR NB cells include delay of cell cycle progression and induction of cell death via TNF-family death receptor activity, thus, targeting both the extrinsic and intrinsic pathway of apoptosis. PAC-1A partially blocked the cell cycle in G2/M phase which correlated with a decrease of the G0/G1 subpopulation, upregulation of cyclin D1 and downregulation of CDK6 and p27 expression. In summary, PAC-1A has demonstrated chemotherapeutic potential to treat a broad spectrum of NBs including highly malignant tumors that show resistance to standard chemotherapeutics and apoptotic stimuli.

\section{Introduction}

Neuroblastoma (NB) is an extracranial solid tumor of sympathetic ganglia and the adrenal medulla predominantly occurring in children. NB accounts for $\sim 50 \%$ of all tumors in the first year of childhood and is the third most common pediatric malignancy after leukemia and central nervous system (CNS) tumors (1). Multimodal treatment methods include surgery, radiation therapy, chemotherapy, autologous stem-cell transplantation depending on the location and biological characteristics of the cancer, stage and the patients risk group (2). Metastasis in lung, liver, bones, the cerebral system and spinal canal are very common (3) and in more than $50 \%$ of children refractory tumors evolve due to the development to drug-resistance (4). Eradication of refractory disease remains one of the most significant challenges in the treatment of high-risk NB. The etiology of NB reveals various potential targets for new drugs such as aberrant Bcl-2-family gene expression (5), MYCN amplification and expression (6) or growth factor pathways (7). The tumor necrosis factor (TNF) signaling pathway is a key player in aggressive NB (8) in which caspase-8, component of the apoptotic death receptor pathway is inactive (9).

Recent research and clinical trials led to innovative new drugs and targeted therapies against NB (10-12). Targeted therapies 
also consider the use of redox-modulating drugs. For example glutathione S-transferases play a predominant role in intrinsic and acquired resistance of NB to anti-cancer drugs (13). In the current report we describe the potential role cranberry proanthocyanidines (PAC) might play in the treatment of high-risk neuroblastoma and various mechanistic modes of action in vitro. The North American cranberry (Vaccinium macrocarpon) is rich in polyphenolic constituents with flavonols, anthocyanins, and PAC with A-type linkage. Due to inherent difficulties in the isolation of single molecule based bioactive constituents, the studies with cranberry PAC extracts in cancer treatment and on cellular response mechanisms have been limited. The effects of related proanthocyanidines from other fruits were described in a variety of antitumor models both in vitro and in vivo (14). For the present report we purified cranberry extract in a series of steps to obtain oligomeric PAC-1A of $97 \%$ purity. The effects of PAC-1A on cytoxicity, cell cycle, modulation of apoptotic markers, ROS generation, glutathion levels and sensitivity of NB cells toward standard drug cyclophosphamide (CP) were described. The present report suggests that PAC-1A display properties as a potential therapeutic drug and chemosensitizer in the treatment of NB.

\section{Materials and methods}

Isolation of oligomeric proanthocyanidines (PAC). Isolation of PAC-1A from fresh cranberry fruit (Vaccinium macrocarpon cv Stevens) was carried out by modifying the previously published protocol (15). Crude proanthocyanidin-rich fractions were initially isolated and purified as described (15) to generate PACs of molecular weight with degree of polymerization ranging from DP-2 to $\leq \mathrm{DP}-19$. These fractions were further purified using MCI gel (CHP 20P, 37-75 $\mu$ ) high porous polymer column $[10-50 \%$ methanol in water $(\mathrm{v} / \mathrm{v})]$ to selectively separate the oligomeric PACs from DP-2 to DP-11 (PACs-1A) from impurities. The PAC-1A composition was characterized using high-performance liquid chromatography (HPLC)-photodiode/ electrochemical detection and matrix-assisted laser desorption/ ionization (MALDI) time-of-flight (TOF) mass spectrometry (16) and further confirmed using LC-MS-MS in product ion scan mode followed by a multiple reaction monitoring (MRM) scan. The identification of high-molecular oligomeric PAC-1A were performed on an API-3000 tandem mass spectrometer (Applied Biosystems, CA, USA) using an electrospray ionization source in negative-ion mode and the following conditions: curtain gas (10 psi), nebulizer gas (9 psi), collisionally activated dissociation gas (6 psi), TurboIonSpray (ion spray) voltage (-4,200 V), entrance potential $(-10 \mathrm{~V})$, collision cell exit potential $(-8 \mathrm{~V})$, source temperature $\left(400^{\circ} \mathrm{C}\right)$, declustering potential $(-60 \mathrm{~V})$. Analytical data were acquired by the Analyst software, version 1.4.2. The product ion spectra for oligomeric PAC and total ion chromatogram in MRM mode are shown in Fig. 1.

Cell culture. SH-SY5Y (human neuroblastoma), IMR-32 (human neuroblastoma) were obtained from American Type Culture Collection (Manassas, VA). SMS-KCNR cells (human neuroblastoma) were provided by Dr J. Maris (CHOP, Philadelphia, PA) and TCL-1 cells (immortalized retroviral large T-antigen transfected trophoblasts) by Dr S. Sharma (Woman \& Infants Hospital, Providence, RI). All cells were seeded at 5x10 $/$ T75 flask (Corning, New York, NY) and cultured to $\sim 80 \%$ confluency according to the suppliers recommendations at $37^{\circ} \mathrm{C}, 5 \%$ $\mathrm{CO}_{2}$ in a humidified incubator.

Cell viability assay. Viability of cell lines treated as indicated (Result Section) with PAC-1A was determined by the CellTiter 96 ${ }^{\circledR}$ AQueous One Solution Assay (Promega Corp., Madison, WI) following the manufacturer's recommendations with suitable modifications as described previously (17).

Western blot analysis. SMS-KCNR cells were seeded into

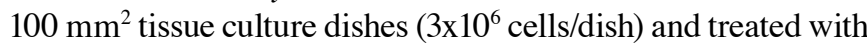
PAC-1A $(25 \mu \mathrm{g} / \mathrm{ml})$ as indicated (Results). Preparation of cell lysates, PAGE and immunoblotting was carried out as described previously (17). Primary antibodies were all purchased from (Cell Signaling Technology, Beverly, MA).

Cell cycle analysis (by FACS). Cell cycle analysis and quantification of apoptosis of SMS-KCNR $\left(1.0 \times 10^{6}\right)$ cells seeded into $100 \mathrm{~mm}^{2}$ cell culture dishes and treated with $20 \mu \mathrm{g} / \mathrm{ml}$ PAC-1A for 24 or $48 \mathrm{~h}$ was carried out by flow cytometry as described previously (17).

Gene siRNA array analysis of PAC-1A treated SMS-KCNR cells. A SureSilencing ${ }^{\mathrm{TM}}$ siRNA array from SABiosciences (catalog no. SAH-012A; www.sabiosciences.com) was used to identify and analyze the role of proapoptotic genes in PAC-1A induced cytotoxicity in SMS-KCNR cells. Validated siRNA (2 sequences per gene, contained in duplicate wells) and appropriate controls were arrayed on a 96-well plate. Controls included a mock transfection, an unspecific siRNA and a fluorescently labeled transfection efficiency control siRNA provided by the manufacturer. Briefly, $37 \mu \mathrm{l}$ of Opti-MEM-I (Invitrogen, catalog no. 51985-034) was added to each well of a 96 well-plate to dissolve the siRNA preloaded in the wells. SureFECT Transfection Reagent (SABiosciences, catalog no. SA-01) was added (35 $\mu \mathrm{l})$ to Opti-MEM-I (315 $\mu \mathrm{l})$ and mixed. This transfection mixture $(3 \mu \mathrm{l})$ was added to each well, the plate incubated at room temperature for $20 \mathrm{~min}$ before SMS-KCNR cells $\left(1 \times 10^{5} / 160 \mu 1\right.$ in RPMI) were added to each well and incubated at $37^{\circ} \mathrm{C}, 5 \% \mathrm{CO}_{2}$ for $24 \mathrm{~h}$. Subsequently, the media was replaced with fresh complete media and cells treated with $25 \mu \mathrm{g} / \mathrm{ml}$ PAC-1A for another $24 \mathrm{~h}$. Cell viability was evaluated as described above.

Analysis of mitochondrial transmembrane depolarization potential $(\Delta \Psi \mathrm{m})$. Analysis of the $\Delta \Psi \mathrm{m}$ of SMS-KCNR cells (1x10\% $/$ well) seeded into 6-well plates and treated with $10 \mu \mathrm{g} / \mathrm{ml}$ PAC-1A for 12 or $24 \mathrm{~h}$ was carried out as described previously (17).

Detection of intracellular reactive oxygen species (ROS). Detection of intracellular ROS in SMS-KCNR $\left(1.0 \times 10^{6}\right)$ cells seeded into $100 \mathrm{~mm}^{2}$ cell culture dishes and treated as indicated (result section) with PAC-1A was carried out by flow cytometry as described previously (18).

Quantification of cellular cyclophosphamide (CP) uptake. SMS-KCNR $\left(3 \times 10^{6}\right)$ cells were seeded in $100 \mathrm{~mm}^{2}$ dishes and treated with PAC-1A $(10 \mu \mathrm{g} / \mathrm{ml})$ or cyclophosphamide $(5 \mu \mathrm{M})$ for $24 \mathrm{~h}$ or pretreated with PAC-1A $(10 \mu \mathrm{g} / \mathrm{ml})$ for $30 \mathrm{~min}$ before 
A
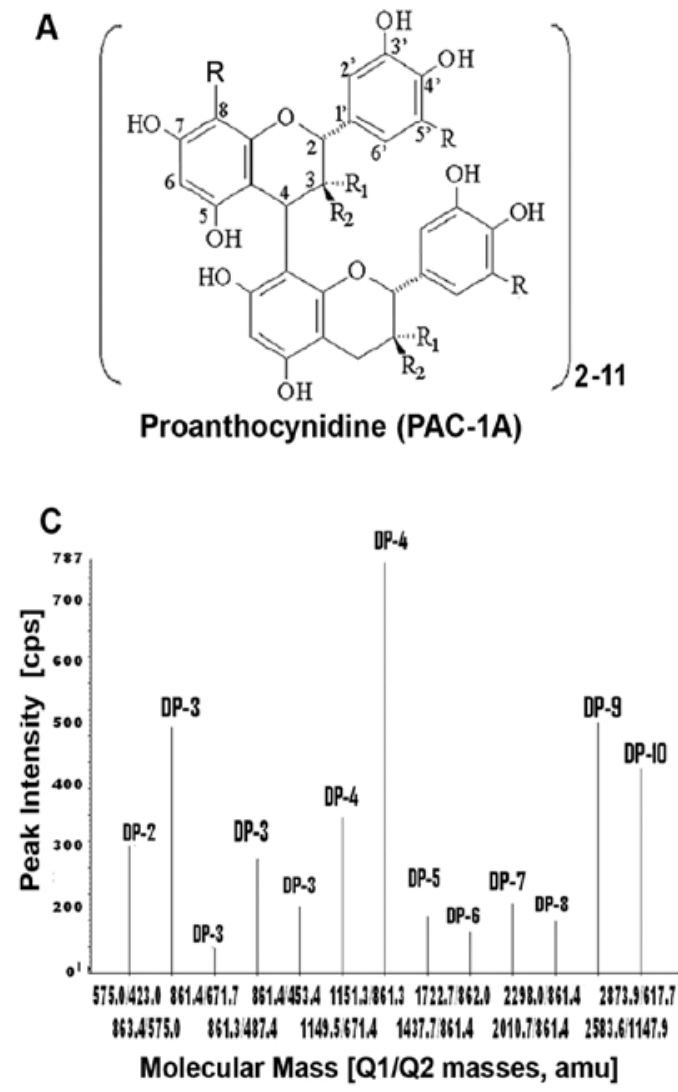

B

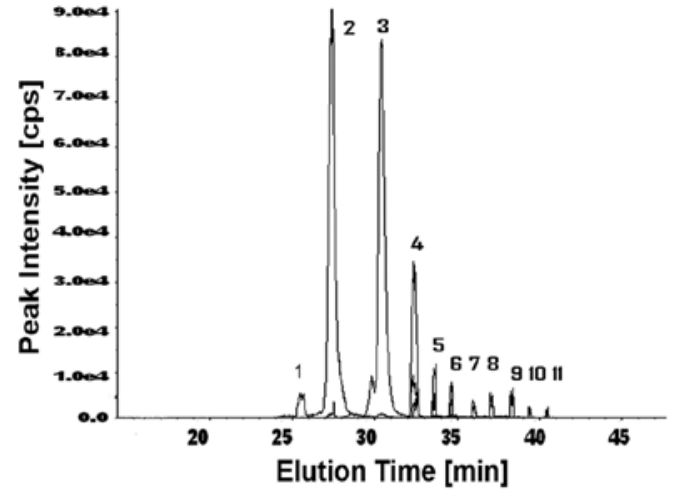

D

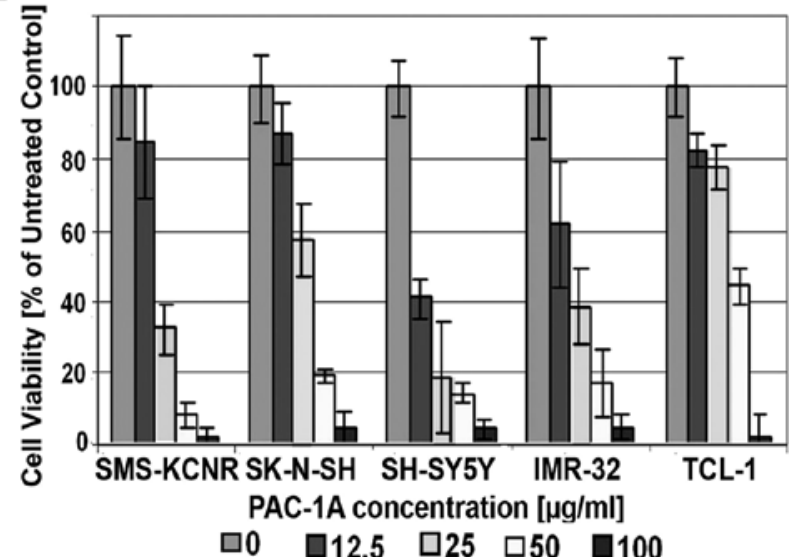

Figure 1. Purification and cytotoxicity of cranberry proanthocynidines (PAC). (A) Chemical structure. PAC display A-type linkage. PAC-1A used in this study consisted primarily of enriched oligomeric proanthocynidines ( $\mathrm{n}=2-11$ ). (B) HPLC profile of PAC-1A (C) LC-MS profile of PAC-1A. DP represents the degree of polymerization. (D) Comparative analysis of the cytotoxic effect of PAC-1A in human NB cell lines. SK-N-SH, SMS-KCNR, IMR-32 and SH-SY5Y NB cell lines and and immortalized trophoblasts (TCL-1) were treated with various concentrations $(0-100 \mu \mathrm{g} / \mathrm{ml})$ of PAC-1A or for $48 \mathrm{~h}$. The MTS viability assay was carried out as described (Materials and methods). Experiments were performed in triplicates; data of a representative experiment are expressed as the mean of triplicate determinations $(\mathrm{X} \pm \mathrm{SD})$ in \% cell viability of samples with untreated cells $(=100 \%)$.

and during combinational treatment with cyclophosphamide (2 $\mu \mathrm{M})$ for $24 \mathrm{~h}$. The supernatant was collected, adherent cells were washed twice with PBS, fixed in $\mathrm{MeOH}$ on ice, treated with acetic acid to stabilize the PACs and extracted with acetonewater $(80 / 20 \% \mathrm{v} / \mathrm{v})$. The extracts were concentrated, $\mathrm{N}_{2}$ flushed and stored at $-80^{\circ} \mathrm{C}$ till analyzed. Uptake of cyclophosphamide was quantified by PE Sciex API 3000 triple-quadropole mass spectrometer (Applied Biosystems) equipped with a turbo ionspray source and attached to Dionex HPLC system (PDA-100, AS 50 Autosampler and GP-50 gradient pump). Cyclophosphamide was separated using Pursuit column (XRs 3,C18 50x2.0 mm, Varian, USA) using mobile phase $A=9: 1$ (v/v) methanol-water with $\mathrm{pH} 3.5$ (formic acid) and mobile phase $\mathrm{B}=2: 2: 6(\mathrm{v} / \mathrm{v} / \mathrm{v})$ methanol, water, acetonitrile with $\mathrm{pH} 3.5$ (formic acid). All experiments were performed in duplicate in positive ion mode. The quantitation of $\mathrm{CP}$ was determined by multiple reaction monitoring (MRM) mode in precursor/product ion pair of $\mathrm{m} / \mathrm{z}$ 261.1/140. Based on our assay, we achieved a high sensitivity level (ng) and calibration curve showed high accuracy and reproducibility. The cellular concentration levels of CP (varied from 2 to $20 \mathrm{ng} / \mathrm{ml}$ ) was achieved.

Estimation of cellular glutathione (GSH) levels. SMS-KCNR $\left(3 \times 10^{6}\right)$ cells were seeded in $100 \mathrm{~mm}^{2}$ dishes and treated with PAC-1A $(10 \mu \mathrm{g} / \mathrm{ml})$ or cyclophosphamide $(5 \mu \mathrm{M})$ or both drugs in combination for $24 \mathrm{~h}$. Subsequently cells were washed twice with PBS, lyzed using cell lysis buffer (cat. no. 9803; Cell Signaling Tech). The assay utilizes monochlorobimane (MCB), a dye that forms adduct with glutathione. The unbound $\mathrm{MCB}$ is nonfluorescent, whereas the dye fluoresces blue (Ex./ Em. $=380 \mathrm{~nm} / 461 \mathrm{~nm}$ ) when bound to glutathione of reduced or oxidized form. The reaction is catalyzed by glutathione S-transferase. The amount of total glutathione was estimated using a Spectra Max Gemini-I fluorometer (Chemicon, MD, USA) fluorometer (emission: 380, excitation: $460 \mathrm{~nm}$ ). Experiments were performed in duplicate.

\section{Results}

Oligomeric proanthocyanidin PAC-1A purification from cranberry; cytotoxicity in NB cell lines. Low yield, poor constituent stability, and high polymerization make difficult the isolation of single molecular weight cranberry proanthocyanidin oligomers, hampering subsequent anti-cancer effect studies. Recently, we obtained more narrowly defined PAC fractions from cranberry by employing HPLC-MS with subsequent characterization by MALDI-TOF techniques to generate PAC-1. PAC-1 was cytotoxic in a panel of cancer cells at concentrations $\geq 125 \mu \mathrm{g} / \mathrm{ml}$ while the viability of control cells (primary lung fibroblasts) was only affected at PAC-1 concen- 
A

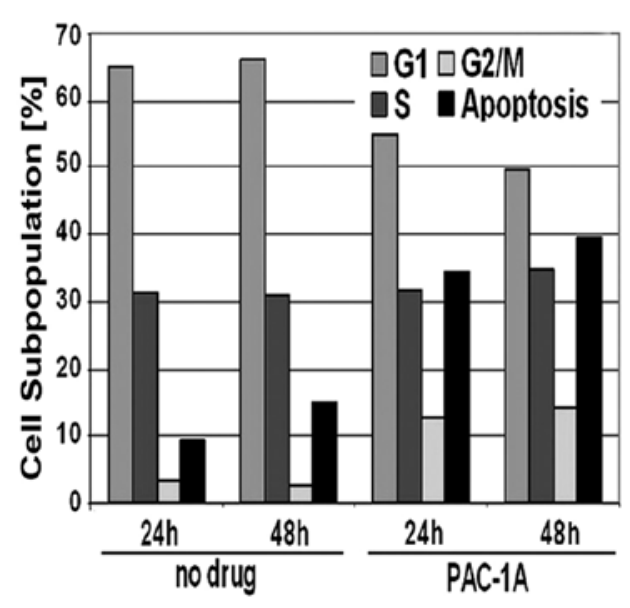

B

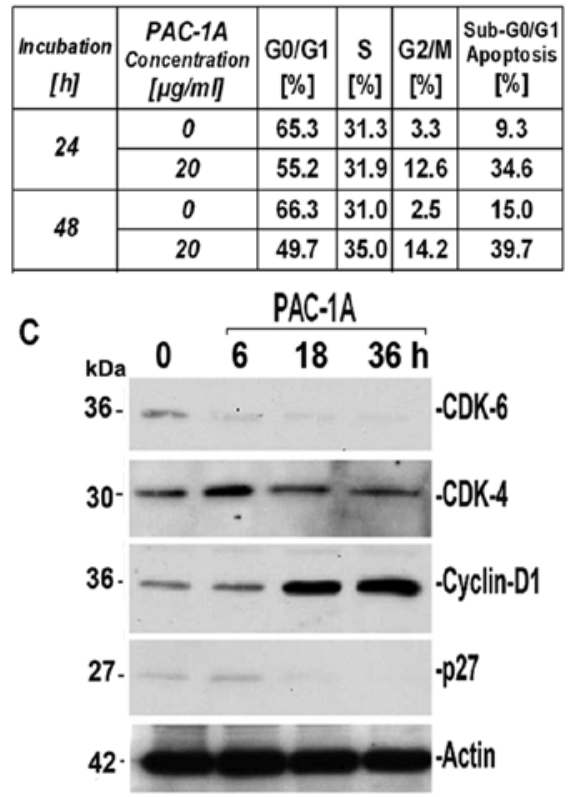

Figure 2. Effect of PAC-1A on cell cycle progression of NB cells. (A) Cell cycle analysis. (A and B) SMS-KCNR cells were treated with $20 \mu \mathrm{g} / \mathrm{ml}$ PAC-1A for 24 or $48 \mathrm{~h}$. FACS analysis of propidium iodide stained cells was carried out as described (Materials and methods). Data are presented as the relative fluorescence intensity of cell subpopulations in a bar chart (A) or in percentage of sub-poulations (B). (C) Expression of cell cycle regulators. SMS-KCNR cells were treated with $20 \mu \mathrm{g} / \mathrm{ml}$ PAC-1A for 6, 18, or $36 \mathrm{~h}$. The expression of CDK-4, -6, of CDK inhibitor p27 and Cyclin-D1 in cellular lysates was analyzed by PAGE and Western blotting (Materials and methods). As an internal standard for equal loading the blots were probed with an anti-actin antibody.

trations $\geq 1 \mathrm{mg} / \mathrm{ml}$ (15). To improve efficacy of PAC-1 for the present study, we carried out further purification employing MCI-Gel CQP serial column-chromatography, followed by Diol HPLC-MS separation techniques to generate PAC-1A (Fig. 1A) with purity (97\%) that composed primarily of oligomeric proanthocynidines (DP2-11) (Fig. 1B) in proportions as described in Fig. 1C.

In an initial approach to analyze effects of PAC-1A on NB cells we performed a viability assay against a panel of NB cell lines (SMSKCNR, IMR-32, SKNSH, SHSY5Y) which each display differential features with respect to caspase-8 deficiency, MYNC amplification, and (N)- and stromal (S)-type morphology (see Discussion). The cells were treated for $48 \mathrm{~h}$ with various concentrations $(12.5-100 \mu \mathrm{g} / \mathrm{ml})$ of PAC-1A and a colorimetric MTS assay performed in which the resulting OD is directly proportional to the number of living cells (19). PAC-1A displayed dose-dependent cytotoxicity (Fig. 1D). All four NB cell lines were more sensitive to treatment than the control cells with an $\mathrm{IC}_{50}$ of $\sim 12.5 \mu \mathrm{g} / \mathrm{ml}$ (SH-SY5Y, IMR-32) or $25 \mu \mathrm{g} / \mathrm{ml}$ (SMS-KCNR, SK-N-SH).

PAC-1A affects cell cycle progression of NB cells. To investigate if PAC-1A affects cell-cycle progression subpopulations of propidium iodide stained SMS-KCNR cells were analyzed by flow cytometry. Treatment with $20 \mu \mathrm{g} / \mathrm{ml}$ PAC-1A led to an increase in the count of subdiploidal/2n cells (apoptotic population; Fig. 2A and B) with $34.6 \%$ apoptotic cells after $24 \mathrm{~h}$ and $39.7 \%$ after $48 \mathrm{~h}$ of treatment. With respect to the cycling cells, PAC-1A caused a stall of progression through G2/M phase and, thus, a decrease of cells in G0/G1 phase. This occurred as early as $24 \mathrm{~h}$ after PAC-1A administration, and with similar results at $48 \mathrm{~h}$ of treatment. Forty-eight hours after seeding untreated cells in this non-synchronous population displayed a confluent monolayer and were to $66.3 .9 \%$ in $\mathrm{G} 0 / \mathrm{G} 1,31 \%$ in $\mathrm{S}$, and $2.5 \%$ in $\mathrm{G} 2 / \mathrm{M}$ phase. The treated cells progression through $\mathrm{G} 0 / \mathrm{G} 1$ after $48 \mathrm{~h}$ was reduced to $49.7 \%$ along with a developing arrest in $\mathrm{G} 2 / \mathrm{M}(14.2 \%)$ and $\mathrm{S}$ phase (35\%) (Fig. 2A and $\mathrm{B})$. Thus, PAC-1A at the moderately cytotoxic concentration of $20 \mu \mathrm{g} / \mathrm{ml}$ exerts antiproliferative effects leading to cell cycle arrest. Western blot analysis of the lysates of SMS-KCNR cells served to investigate the expression of cell cycle regulatory factors upon PAC-1A treatment. PAC-1A at $20 \mu \mathrm{g} / \mathrm{ml}$ caused strong and prolonged up-regulation of cyclin-D1 within $18 \mathrm{~h}$ of treatment and up-regulation of CDK-4 within $6 \mathrm{~h}$ of treatment with return to basic levels after 18 or $36 \mathrm{~h}$ (Fig. 2C). CDK-6 and p27 expression after PAC-1A treatment was down-regulated from the basic level within $6 \mathrm{~h}$ of treatment with signals reaching background levels at $36 \mathrm{~h}$ (Fig. 2C).

PAC-1A affects the mitochondrial membrane depolarization potential of $N B$ cells and increases generation of ROS. To understand the mechanism involved in the cellular response to PAC-1A treatment we examined the mitochondrial transmembrane depolarization potential $(\Delta \Psi \mathrm{m})$ of SMS-KCNR cells by flow cytometry (Fig. 3A). PAC-1A at $10 \mu \mathrm{g} / \mathrm{ml}$ caused a rapid loss of $\Delta \Psi \mathrm{m}$ within $12 \mathrm{~h}$ which increased within $24 \mathrm{~h}$ of treatment (shift in the fluorescence intensity profile to the left). Loss of $\Delta \Psi \mathrm{m}$ due to chemical agents is considered as onset of early apoptotic events (20). Cytotoxic action by anti-cancer drugs is correlated to the generation of reactive oxygen species (ROS) (21). We tested the effect of PAC-1A treatment on the generation of ROS in SMS-KCNR cells. Hydrogen peroxide $\left(\mathrm{H}_{2} \mathrm{O}_{2}\right)$, hydroxyl radicals $\left(\mathrm{HO}^{\circ}\right)$, and peroxyl radicals (ROO') were detected via carboxy-H2DCFDA by flow cytometry. As 
A

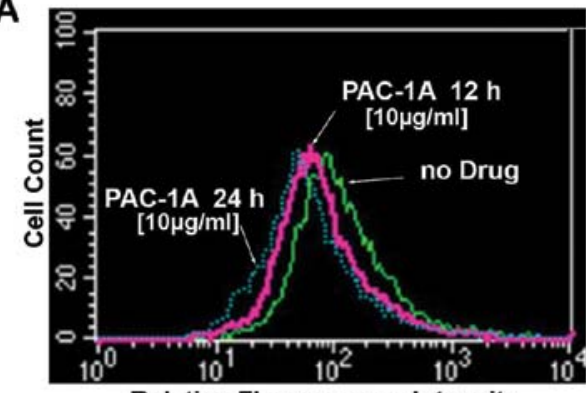

Relative Fluorescence Intensity

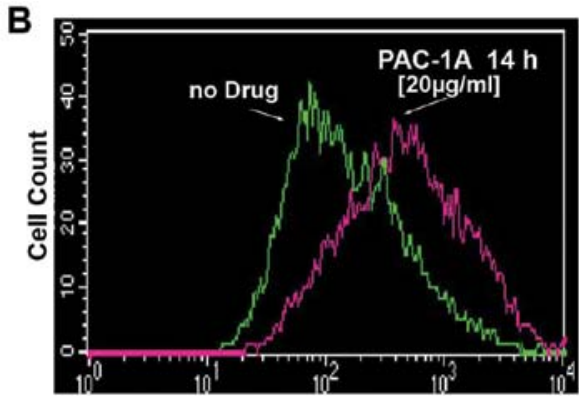

Relative Fluorescence Intensity
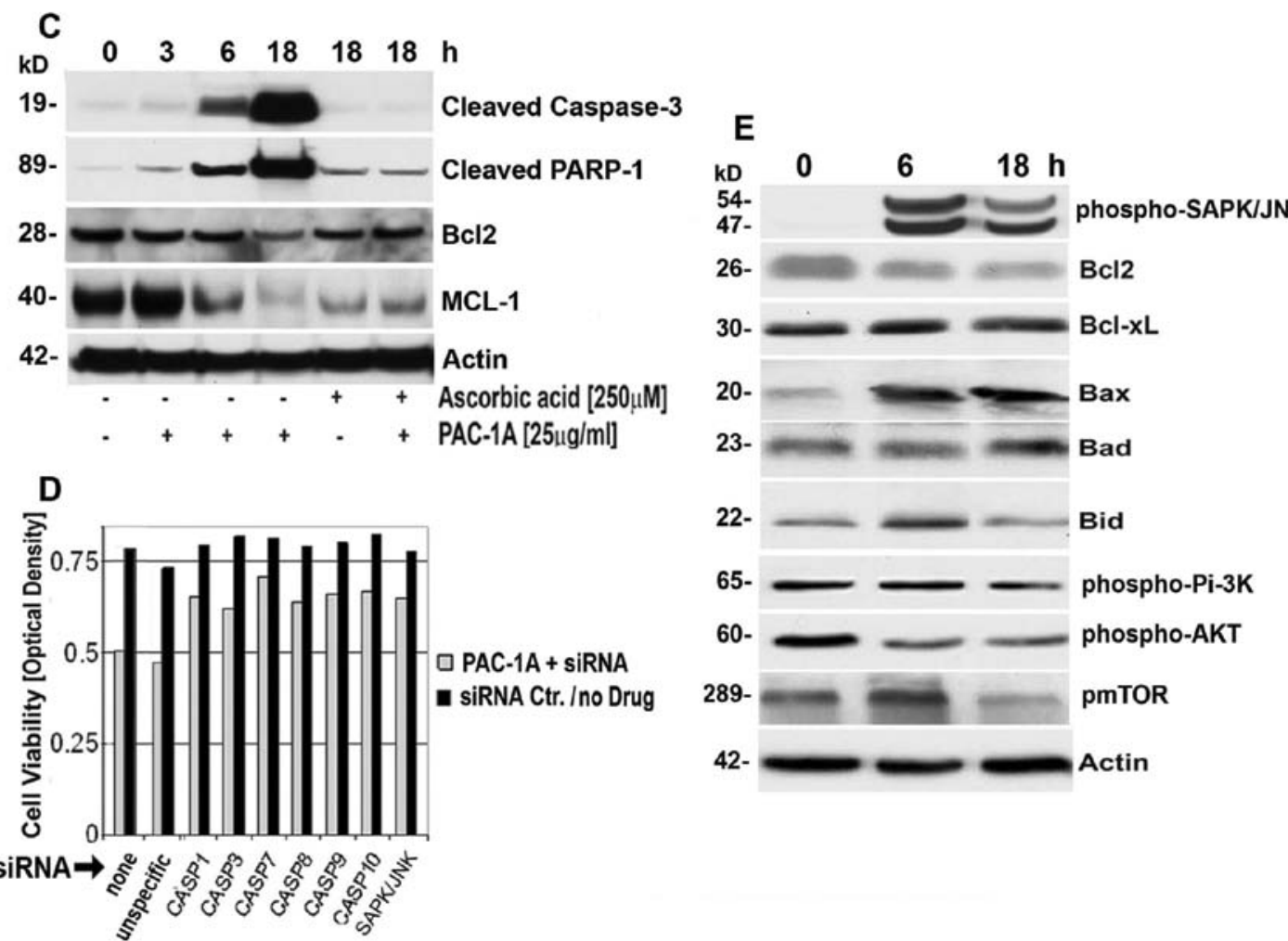

Figure 3. Induction of apoptosis and ROS generation by PAC-1A in NB cells. (A) Membrane depolarization analysis. SMS-KCNR cells were treated for 12 or $24 \mathrm{~h}$ with $10 \mu \mathrm{g} / \mathrm{ml}$ PAC-1A, fixed and stained (Materials and methods), and the mitochondrial transmembrane depolarization potential ( $\Delta \Psi \mathrm{m}$ ) of the single cell populations was analyzed by FACS. Ten thousand cells were analyzed in each sample. (B) ROS generation. Generation of ROS in SMSKCNR cells following 14-h treatment with $20 \mu \mathrm{g} / \mathrm{ml}$ PAC-1A was analyzed by FACS (Materials and methods). (C) Expression of apoptotic markers in NB cells after PAC-1A treatment with and without inhibition of ROS generation. SMS-KCNR cells were treated with PAC-1A $(25 \mu \mathrm{g} / \mathrm{ml})$ alone $(3,6,18 \mathrm{~h})$ or in combination with antioxidant ascorbic acid $(250 \mu \mathrm{M})$ for $18 \mathrm{~h}$. Immunoblotting was carried out with primary antibodies against cleaved/inactivated PARP-1, cleaved/activated caspase-3, and pro-survival Bcl-2 and MCL-1. As an internal standard for equal loading, blots were probed with an anti-actin antibody. (D) Effect of silencing of caspase genes and SAPK/JNK on PAC-1A mediated cytotoxicity. The role of various pro-apoptotic genes in PAC-1A induced cytotoxicity in SMS-KCNR cells was analyzed in a siRNA array (Materials and methods). Viability of cells neither treated with siRNA (mock transfection) nor PAC-1A or treated with an unspecific siRNA (negative control) served as reference. Cells were treated with PAC-1A $(25 \mu \mathrm{g} / \mathrm{ml})$ for $24 \mathrm{~h}$, an MTS assay was carried out and the cell viability depicted as optical density. (E) Expression of pro-survival factors and mitochondrial regulators of apoptosis. SMS-KCNR cells were treated with PAC-1A $(25 \mu \mathrm{g} / \mathrm{ml})$ for 6 or $18 \mathrm{~h}$ and immunoblotting was carried out with primary antibodies against Bcl-2 family proteins with prosurvival (Bcl-2, Bcl-xL) or pro-apoptotic (Bax, Bad, Bid) function, against activated pro-apoptotic SAPK/JNK or against key proteins in the PI3K/AKT/mTOR pro-survival pathway.

shown in Fig. 3B, ROS generation in NB cells increased (shift in the fluorescence intensity profile to the right) following treatment of cells with $20 \mu \mathrm{g} / \mathrm{ml}$ PAC-1A (for $14 \mathrm{~h}$ which correlated with a reduction in cell viability by this drug (Fig. 1D).

Expression of apoptotic markers in NB cells after PAC-1A treatment with and without inhibition of ROS generation. To define key signaling responses of $\mathrm{NB}$ cells in response to PAC-1A treatment, we analyzed by Western blotting the activation/inactivation of various apoptotic markers such as caspase-3, PARP-1, MAPK
SAPK/JNK and two prosurvival proteins linked to the intrinsic pathway of apoptosis, Bcl-2 and MCL-1. Moreover, we analyzed the role of ROS in regulation of these factors and the subsequent onset of cell death by treating cells with antioxidant ascorbic acid. SMS-KCNR cells were treated with PAC-1A $(25 \mu \mathrm{g} / \mathrm{ml})$ alone $(3,6$ and $18 \mathrm{~h})$ or in combination with antioxidant ascorbic acid $(250 \mu \mathrm{M})$ for $18 \mathrm{~h}$. Immunoblotting of PAGE-separated cellular lysates revealed that PAC-1A caused a rapid (within $3 \mathrm{~h}$ ) and sustained activation/cleavage of effector caspase- 3 and inactivation/cleavage of DNA repair factor PARP-1 (Fig. 3C). 
Pro-survival factors BCL-2 and MCL-1 were downregulated within $6 \mathrm{~h}$ of PAC-1A treatment. Co-treatment of the cells with ascorbic acid completely abolished the activation of caspase- 3 by PAC-1A and blocked strongly the inactivation of PARP-1 and downregulation of BCL-2 expression by this cytotoxic drug (Fig. 3C). The signals for these three factors were not modified by treatment with ascorbic acid alone. Even though MCL-1 expression was diminished in controls of cells treated with ascorbic acid alone, ascorbic acid appeared to partially block the down-regulatory effect of PAC-1A on MCL-1 expression. These findings indicate that PAC-1A induced generation of ROS in NB cells caused the activation of proapoptotic and de-activation or reduction of expression of various pro-survival factors, thus, promoting cell death.

Effect of caspase- and SAPK/JNK gene silencing on PAC-1Ainduced cell death. The role of effector caspases (such as caspase-3 and -7), inflammatory caspase-1, initiator caspases of the extrinsic/ death receptor induced pathway (caspase-8, -10) and intrinsic apoptotic pathway (caspase-2, -9), and of SAPK/JNK MAPK in PAC-1A induced cell death of SMS-KCNR was analyzed via a siRNA array. Activity of SAPK/JNK has been linked to induction of the intrinsic pathway of apoptosis and of ROS generation in NB (SK-N-SH) cells (22). Viability of cells neither treated with siRNA (mock transfection) nor PAC-1A served as reference. As shown in Fig. 3D the use of an unspecific siRNA (negative control) did not diminish the cytotoxic effect of PAC-1A. However, silencing of the genes encoding caspase-1, $-3,-7,-8,-9$, and -10 reduced PAC-1A induced cell death by 40-60\% depending on the gene targeted. Therefore, apoptosis in SMSKCNR cells induced by PAC-1A appears to be mediated partially by both, the intrinsic/mitochondrial and extrinsic pathway of apoptosis. Similarly, silencing of the gene encoding SAPK/JNK blocked the cytotoxic effect of PAC-1A by more than half. Accordingly, immunoblotting revealed that in SMS-KCNR cells treated for 6 or $18 \mathrm{~h}$ with PAC-1A $(25 \mu \mathrm{g} / \mathrm{ml})$ the activity/phosphorylation of the SAPK/JNK protein was strongly induced suggesting that this MAPK plays a key role in mediating NB cell death.

Effect of PAC-1A on the expression of mitochondrial regulators of apoptosis and pro-survival signaling. Aberrant expression of Bcl-2 family proteins are the major determinants of the progression of NB and the effectivity of chemotherapy. We examined the modulation of expression of these mitochondrial proteins. SMS-KCNR cells were treated with PAC-1A $(25 \mu \mathrm{g} / \mathrm{ml})$ for 6 or $18 \mathrm{~h}$ and immunoblotting was carried out with primary antibodies against Bcl-2 family proteins with pro-survival (Bcl-2, $\mathrm{Bcl}-\mathrm{xL}$ ) or pro-apoptotic (Bax, Bad, Bid) function. PAC-1A treatment changed the expression levels of all examined $\mathrm{Bcl}-2$ family proteins. Within 18-h expression of Bcl-2 and Bcl-xL was partially inhibited, while Bad expression increased. Expression of Bax and Bid was elevated after $6 \mathrm{~h}$ of treatment (Fig. 3E). Neither of these changes was as strong as the downregulation observed for MCL-1 (Fig. 3C) but support the finding that PAC-1 partially mediates cytotoxicity via the intrinsic apoptotic pathway. In the context of the effect of PAC-1A on pro-survival signaling of NB cells we included immunoblotting analysis with antibodies against key proteins of the PI3K/AKT/mTOR pathway. Significant expression of activated AKT and mamma- lian target of rapamycin (mTOR) can be detected in primary neuroblastoma tissues and their inactivation is correlated to anti-proliferative effects on NB cells in vitro and in vivo (23). SMS-KCNR cells after treatment for 6-18 h with PAC-1A displayed a reduced level of phosphorylation/activation of PI- 3K, AKT as well as of the expression of mTOR (Fig. 3E). In summary, PAC-1A exerts effects through modulation of various mediators of signaling events such as the Bcl-2 protein family and the $\mathrm{Pi} 3 \mathrm{~K} / \mathrm{AKT} / \mathrm{mTOR}$ pathway.

Effect of TNF-family gene silencing and TNF receptor expression in NB after PAC-1A treatment. Various high-risk NB cell lines express the tumor necrosis factor- $\alpha$ (TNF $\alpha)$ and TNF receptors $(8,24)$. Induction of the extrinsic pathway of apoptosis which contributes to the cytotoxic action of PAC-1A is generally initiated by ligation of transmembrane death receptors such as the TNF receptor family. We analyzed by Western blotting the activation/phosphorylation of the TNF $\alpha$ receptor. SMSKCNR cells were treated with recombinant TNF $\alpha(10 \mathrm{nM})$ for $30 \mathrm{~min}$ and with PAC-1A $(25 \mu \mathrm{g} / \mathrm{ml})$ for $24 \mathrm{~h}$ or treated with either agent alone. Untreated cells or cells treated with $\mathrm{TNF} \alpha$ displayed a high level of receptor activation. In contrast, PAC-1A treatment reduced $\mathrm{TNF} \alpha$ receptor phosphorylation to background levels in the presence or absence of the recombinant ligand (Fig. 4A). Via a siRNA array we analyzed the involvement of gene products that are either part of TNF-family or considered directly regulated by TNF in PAC-1A induced cell death of SMS-KCNR. As shown in Fig. 4B the use of an unspecific siRNA (negative control) did not alter the cytotoxic effect of PAC-1A. However, silencing of various genes of the TNF receptor superfamily (e.g., TNFRSF10A, -10B, -21, -25) except for TNFRSF1A reduced PAC-1 induced cell death by $>50 \%$ depending on the gene targeted. Similarly, knock-down of various genes directly regulated by TNF (e.g., FADD, DIABLO, CRADO, RIPK2, TRADD, TRAFF, p53) reduced the PAC-1A induced cytotoxicity significantly $(>40 \%)$. These preliminary experiments suggest a major role of TNF receptor pathways in the mediation of PAC-1A cytotoxicity in SMS-KCNR NB cells.

PAC-1A enhances the uptake/retention of cyclophosphamide; co-treatment increases cytotoxicity and expression on pro-apoptotic markers, reduces GSH levels and expression of SOD in NB cells. We investigated the impact of PAC-1A in the modulation of cellular uptake, respectively, retention by SMS-KCNR cells of cyclophosphamide (CP), a clinically used drug. In addition, the cytotoxicity, cellular presence of glutathione (GSH) and expression of pro-apoptotic markers and superoxide dismutase (SOD) under treatment with PAC-1A and/or CP was analyzed. To quantify the presence of intracellular CP, SMS-KCNR cells were treated with $\mathrm{CP}(5 \mu \mathrm{M})$ for $24 \mathrm{~h}$ (Fig. 5A) or pretreated with PAC-1A $(10 \mu \mathrm{g} / \mathrm{ml})$ for $30 \mathrm{~min}$ before and during combinational treatment with $\mathrm{CP}(2 \mu \mathrm{M})$ for $24 \mathrm{~h}$ (Fig. 5B). Comparison of both HPLC-MS-MS fractions in MRM mode reveals that relatively more intracellular $\mathrm{CP}$ is present when the cells were treated with PAC-1A even though the amount of $\mathrm{CP}$ added to the culture media was half ( $5 \mu \mathrm{M}$ instead of $10 \mu \mathrm{M}$ final concentration) under co-treatment conditions. Fig. 5A depicts the total ion chromatogram of CP in SMSKCNR cells (treated with CP in absence of PACs). Fig. 5B exhibits total ion chromatogram of $\mathrm{CP}$ in SMSKCNR cells (treated with CP in presence of PAC-1A). 
A

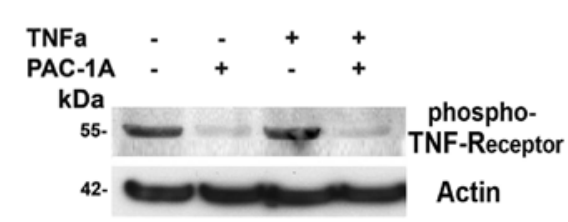

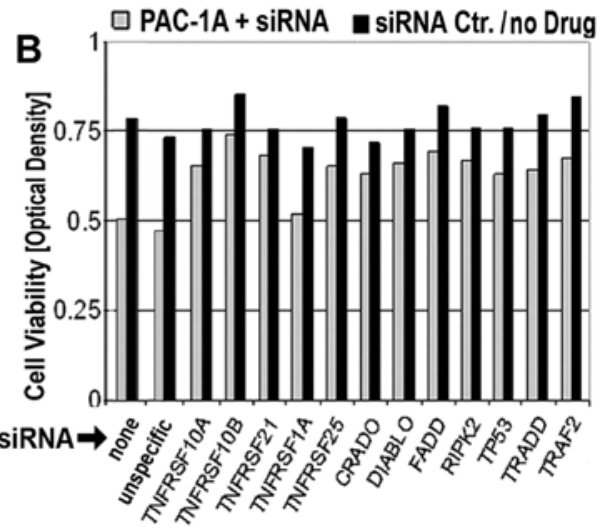

Figure 4. Effect of PAC-1A on TNF receptor activation and of TNF-family gene silencing on PAC-1A mediated cytotoxicity. (A) Activation of the TNF receptor by PAC-1A in NB cells. SMS-KCNR cells were treated with TNF $\alpha(10 \mathrm{nM})$ for $30 \mathrm{~min}$ or with PAC-1A $(25 \mu \mathrm{g} / \mathrm{ml})$ for $24 \mathrm{~h}$ either alone or in combination and immunoblotting was carried out with an antibody against the phosphorylated form of the TNFa receptor. As an internal standard for equal loading, blots were probed with an anti-actin antibody. (B) Effect of silencing of caspase genes and SAPK/JNK on PAC-1A mediated cytotoxicity. The role of various genes of the TNF receptor family or of gene products that are directly regulated by TNF receptor signaling in the PAC-1A induced cell death of SMS-KCNR was analyzed in a siRNA array (Materials and methods). Viability of cells neither treated with siRNA (mock transfection) nor PAC-1A or treated with an unspecific siRNA (negative control) served as reference. Cells were treated with PAC-1A $(25 \mu \mathrm{g} / \mathrm{ml})$ for $24 \mathrm{~h}$, an MTS assay carried out and the cell viability depicted as optical density.
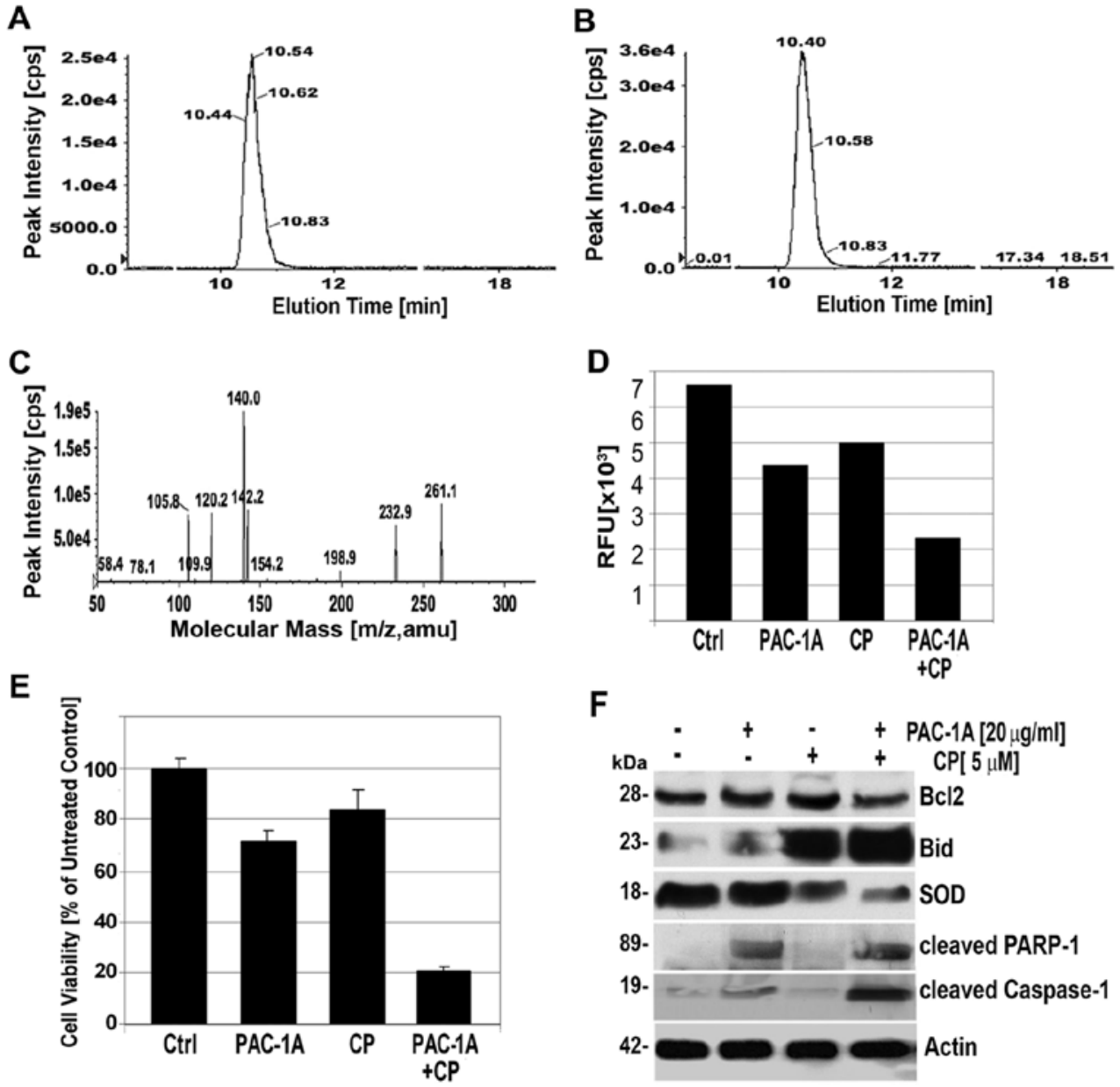

Figure 5. Effect of PAC-1A on cyclophosphamide (CP) uptake/retention, cytotoxicity, gluthathione (GSH) production and apoptotic markers in NB cells (A and B) HPLC quantification of intracellular CP in PAC-1A treated NB cells. SMS-KCNR cells were treated with CP $(5 \mu \mathrm{M})$ for $24 \mathrm{~h}(\mathrm{~A})$ or pretreated with PAC-1A $(10 \mu \mathrm{g} / \mathrm{ml})$ for 30 min before and during combinational treatment with CP $(2 \mu \mathrm{M})$ for $24 \mathrm{~h}(\mathrm{~B})$. LC-MS profile of the cellular content of CP are shown (C) LCMS profile of CP. SMS-KCNR cells were pretreated with PAC-1A $(10 \mu \mathrm{g} / \mathrm{ml})$ for 30 min before and during combinational treatment with CP $(2 \mu \mathrm{M})$ for $24 \mathrm{~h}$. The cellular content of CP was analyzed by LC-MS. (D) Estimation of cellular content of GSH. SMS-KCNR cells were treated with PAC-1A (10 $\mu \mathrm{g} / \mathrm{ml})$ or $\mathrm{CP}(5 \mu \mathrm{M})$ or in combination for $24 \mathrm{~h}$. The fluorimetric estimation of cellular content of GSH is described in Materials and methods. (E) Cytotoxicity of treatment with PAC-1A and CP. SMS-KCNR cells were treated with PAC-1A $(10 \mu \mathrm{g} / \mathrm{ml})$ or $\mathrm{CP}(5 \mu \mathrm{M})$ or in combination for $24 \mathrm{~h}$. Experiments were performed in triplicates; data of a representative experiment are expressed as the mean of triplicate determinations (X $\pm \mathrm{SD})$ in \% cell viability of samples with untreated cells $(=100 \%)$. (F) Effect of PAC-1A and CP co-treatment on expression of apoptotic markers. SMS-KCNR cells were treated with PAC-1A (20 $\mu \mathrm{g} / \mathrm{ml})$ or CP $(5 \mu \mathrm{M})$ alone or in combination for $24 \mathrm{~h}$. Expression of Bcl-2, Bid, SOD-1, cleaved PARP-1 and cleaved caspase-3 was analyzed by Western blotting. As an internal standard for equal loading, blots were probed with an anti-actin antibody. 
Fig. 5C depicts the MS-MS fragmentation of CP in SMSKCNR cells pretreated with PAC-1A. PAC-1A treatment $(10 \mu \mathrm{g} / \mathrm{ml}$ for $24 \mathrm{~h}$ ) decreased the intracellular level of GSH by $35 \%$ and treatment with $5 \mu \mathrm{M} \mathrm{CP}$ (for $24 \mathrm{~h}$ ) by $25 \%$. Combinational treatment of SMSKCNR cells with these two drugs displayed a synergistic effect on GSH levels which were reduced by $69 \%$ under co-treatment conditions for $24 \mathrm{~h}$ (Fig. 5C). In addition, a synergistic effect on cell viability was observed when SMSKCNR cells were co-treated for $24 \mathrm{~h}$ with $10 \mu \mathrm{g} / \mathrm{ml}$ PAC-1A and $5 \mu \mathrm{M}$ CP (Fig. 5E). Cytotoxicity under combinational treatment was $80 \%$ whereas PAC-1A alone reduced the viability by only $27 \%$ and $\mathrm{CP}$ alone by $17 \%$. Western blotting of cellular lysates after co-treatment of SMS-KCNR cells with PAC-1A and CP revealed additive effects on the expression of apoptotic markers and SOD (Fig. 5F). PAC-1A CP treatment at $20 \mu \mathrm{g} / \mathrm{ml}$ alone for $24 \mathrm{~h}$ did not significantly alter the expression of Bcl-2, Bid, SOD while caspase-1 was slightly activated and PARP-1 slightly deactivated. $\mathrm{CP}$ treatment at $5 \mu \mathrm{M}$ alone for $24 \mathrm{~h}$ increased the expression of Bid, reduced the expression of SOD but did not significantly alter the level of Bcl-2, caspase-1 activation or PARP-1 deactivation. Co-treatment with both drugs reduced the expression of Bcl-2, strongly suppressed SOD expression, increased dramatically the levels of BID, activated caspase-1 and deactivated PARP-1. In summary synergistic or additive effects in cytotoxicity, GSH reduction, and modulation of apoptotic markers and SOD during cotreatment of SMS-KCNR with PAC-1A and CP were observed.

\section{Discussion}

The anti-cancer and chemo-preventive properties of cranberry extracts have been the subject of recent studies in ovarian (15), breast cancer (25) and other cancer lines (26). Isolation of pure proanthocyanidin (PAC) fractions from cranberry continues to be the major impediment in studying medical and biological effects of these compounds (27). For the present study, we optimized the enrichment of PAC using a polymer-separation capable HPLC/LC-MS, to generate a highly bioactive oligomeric fraction (PAC-1A, 2-11 oligomers) with high purity $(>97 \%)$ and characterized molecular weight. Further resolution of the oligomeric mixture (PAC-1A) into single chemical entities (SCEs), although very challenging, is in progress. The present study reveals that PAC are potent cytotoxic agents against various neuroblastoma cell lines in vitro while reduction of the cell viability of control cells (non-malignant immortalized trophoblasts) or, as shown in a recent study, primary fibroblasts (15) requires higher PAC concentrations. The NB cell lines (SMS-KCNR, IMR-32, SKNSH, SHSY5Y) employed in this study represent a spectrum of morphological and various common oncogenic and chemoresistancy features of highrisk neuroblastoma (28-30). IMR-32 cells feature (N)-type morphology and MYCN- amplification (31). IMR-32, SKNSH, SHSY5Y cells lack caspase-8 expression (32) and induction of apoptosis is primarily mediated through the intrinsic pathway. These three cell lines reflect the majority of NB which lack the expression of caspase- 8 , sensitivity to the extrinsic pathway of apoptosis and are refractory to multiple cytotoxic drugs. In these cells the extrinsic and TNF-related pathway of apoptosis can only be induced in combinational treatment with factors such as cytostatic drugs, interferon- $\gamma$ or TRAIL (TNF-related apoptosis-inducing ligand) (33). However, all these three high-risk NB cell lines were sensitive to PAC-1A treatment $\left(\mathrm{IC}_{50} 12.5-25 \mu \mathrm{g} / \mathrm{ml}\right)$. PAC-1 A at these concentrations also displayed cytotoxicity against the fourth cell line, SMS-KCNR, in the panel of NB cells studied. These data confirm the higher potency of the more defined extract of PAC-1A achieved with the current isolation protocol when compared to our previous study including SMSKCNR (15). SMS-KCNR cells exhibit a uniform phenotype with small, round N-type cells that have short neuritic processes (34). This cell line was chosen as a model for mechanistic experiments in the current report since they display MYCN amplification, express caspase-8 (35) and apoptosis can be mediated through the intrinsic as well as extrinsic pathway (36). PAC-1A, however, induced cell death of SMS-KCNR through both apoptotic pathways via: i) modulation of expression of these mitochondrial $\mathrm{Bcl}-2$ family proteins with pro-survival (Bcl-2, Bcl-xL) or pro-apoptotic (Bax, Bad, Bid) function, ii) TNF-family regulated extrinsic/death receptor signaling, and iii) activation of pro-apoptotic MAPK (e.g., SAPK/JNK) and suppression of pro-survival signaling through the PI3K/AKT/mTOR pathway. All these cellular targets of PAC-1A are of interest in the search for alternative drugs to treat NB. Aberrant Bcl-2 family protein expression promotes chemo-refractory high-risk NB and selective inhibitors against pro-survival proteins of the Bcl-2 family have been developed to treat NB $(37,38)$. Induction of the extrinsic pathway of apoptosis is generally initiated by ligation of transmembrane death receptors such as the TNF receptor family. Their activity as shown in the present manuscript contributes to the cytotoxic action of PAC-1A. In addition to these receptors NB cells, as shown for various high-risk NB cell lines, also express the tumor necrosis factor- $\alpha(\mathrm{TNF} \alpha)$ which can stimulate growth in an autocrine manner (8). Modulation of TNF receptor signaling is a promising additional approach in cancer therapy $(39,40)$. Similarly, inhibitors against mTOR such as rapamycin and CCI-779 downregulate MYCN protein expression and inhibit neuroblastoma tumorigenesis (19). As shown here for high risk SMS-KCNR NB cells PAC-1A in its ability to target all the factors above might be developed as a chemotherapeutic agent against a broad spectrum of NB including highly malignant NB (41).

The present study reveals that the cytotoxic effect and induction of apoptosis by PAC-1A is executed by the loss of the mitochondrial transmembrane depolarization potential $(\Delta \Psi \mathrm{m})$ and by excess generation of ROS. Loss of $\Delta \Psi \mathrm{m}$ is directly linked to the degradation of mitochondrial proteins (e.g., Bcl-2, $\mathrm{MCl}-1)$ and is an indicator of early apoptosis and the first irreversible step in the induction of apoptosis (18). Reactive oxygen species play a critical role in differentiation, proliferation and apoptosis in NB (42). Generally, ROS have been implicated in cancer initiation and progression (43). Cancer cells generate a relatively high level of ROS but their tolerance to ROS compares to non-transformed cells. Accordingly, further up regulation of cellular ROS, such as shown here after treatment with PAC-1A can be used to selectively target cancer cells over normal cells (44). ROS production in NB cells is correlated with multitude of signal transduction such as the activation of the JNK/SAPK or other pro-apoptotic MAPK, loss of $\Delta \Psi \mathrm{m}$ and translocation or degradation of mitochondrial key proteins of the intrinsic apoptotic pathway (45). Accordingly, as shown here the PAC-1A induced loss of Bcl-2 and MCL-1, deactivation of PARP-1 
and executor caspase-3 in SMS-KCNR NB cells could be partially inhibited by the block of excessive ROS generation via co-treatment with an anti-oxidant. Interestingly, several studies have shown that ROS generation is the key mechanism of cytotoxicity for several common chemotherapeutic drugs including cisplatin, cyclophosphamide and fenretidine that are in clinical use or in trials to treat NB (46).

The intrinsic and acquired resistance of NB tumors to anticancer drugs frequently correlates with the level of glutathione (GSH) S-transferases and GSH which play a key role to avoid oxidative stress and to bypass cytotoxicity of therapeutic drugs (47). However, overcoming drug resistance often requires reducing GSH levels by $60-80 \%$ (48). Thus, one aspect in the use of newly developed drugs in single agent treatment or in combinational treatment with standard drugs is their ability to reduce GSH levels (49). In the present report we investigated the capacity of PAC-1A to develop synergistic effects with cyclophosphamide (CP). $\mathrm{CP}$ is an alkalyting anti-neoplastic agent and commonly used for NB treatment. We show here that PAC-1A can partially lower GSH levels in NB cells. However, GSH levels were dramatically reduced when the cells were co-treated with PAC-1A and CP which correlated to additive cytotoxic effects. Similarly, a proanthocyanidin fraction from cranberry fruit showed synergistic cytotoxic actions with paraplatin in platinum resistant ovarian cancer cells (15). Interestingly, the potentiated cytotoxic effect of PAC-1 and CP was correlated with an increased uptake and/or retention of CP in PAC-1A treated SMS-KCNR NB cells. In addition, the expression of apoptotic markers and superoxide dismutase (SOD) under treatment with PAC-1A and CP was altered when compared to treatment with either drug alone. The present study suggests that PAC-1A, in addition to specific cytotoxic properties displays inhibitory effects on NB proliferation since it blocked cell-cycle progression of SMS-KCNR. Interestingly, after treatment with PAC-1A we observe opposite effects on the expression of CDK-4 and 6. Generally, cyclin D-dependent kinases such as CDK-4 and -6 are regulators of $\mathrm{G} 1$ and facilitate cell progression in various ways (including sequestering and redistribution of Kip proteins). Moreover, cyclin-D1 correlated to G1 phase progression (50) and was strongly over expressed upon PAC-1A treatment while the population of NB cells in G1 phase decreased and an arrest was unfolded in $\mathrm{G} 2$ phase. In addition, PAC-1A treatment blocked expression of CDK inhibitor p27/KIP1. Overexpression of key cell cycle regulators, such as CDK-4 and CDK-6 targeted by PAC-1A often correlates with histological high-risk features of NB. Targeting such checkpoints has been suggested as an alternative approach to anti-cancer therapies (51).

In conclusion, the present study suggests that PAC-1A can be developed for single-drug or combinational treatment of NB. PAC-1A mediated ROS generation or GSH reduction may exert synergistic effects when combined with other standard drugs such as cyclophosphamide or agents, thought to modulate the antioxidant functions of cancer cells. Moreover, features of PAC-1A as an anticancer drug include the induction of cell death via: i) modulation of expression of mitochondrial Bcl-2 family proteins members, ii) regulation of TNF-family death receptor signaling, and iii) activation of pro-apoptotic MAPK or suppression of pro-survival signaling through the PI3K/AKT/mTOR pathway. The ability of PAC-1A to target many oncogenic factors related to NB above suggests further exploration of PAC-1A as a chemotherapeutic agent to treat a broad spectrum of NB, including highly malignant and chemoresistant tumors.

\section{Acknowledgements}

A.P.S. and N.V. are grateful to Mr. Graham Gibson, Applied Biosystems, for his kind gift of the API-3000 LC-MS-MS instrument, and USDA-CREES for funding support via grant (SRG88-34155-3491). Part of this research was supported by a 'Swim Across America' fund to R.K.S. and R.G.M.

\section{References}

1. Brodeur GM, Pritchard J, Berthold F, Carlsen NL, Castel V, Castelberry RP, Bernardi B, De Evans AE, Favrot M and Hedborg F: Revisions of the international criteria for neuroblastoma diagnosis, staging, and response to treatment. J Clin Oncol 11: 1466-1477, 1993.

2. Matthay KK, Perez C, Seeger RC, Brodeur GM, Shimada H, Atkinson JB, Black CT, Gerbing R, Haase GM, Stram DO, Swift P and Lukens JN: Successful treatment of stage III neuroblastoma based on prospective biologic staging: a Children's Cancer Group study. J Clin Oncol 16: 1256-1264, 1998.

3. DuBois SG, Kalika Y, Lukens JN, Brodeur GM, Seeger RC, Atkinson JB, Haase GM, Black CT, Perez C, Shimada H, Gerbing R, Stram DO and Matthay KK: Metastatic sites in stage IV and IVS neuroblastoma correlates with age, tumor biology and survival. J Pediat Hematol Oncol 21: 181-189, 1999.

4. Maris JM and Matthay KK: Molecular biology of neuroblastoma. J Clin Oncol 1999: 2264-2279, 1999.

5. Niizuma H, Nakamura Y, Ozaki T, Nakanishi H, Ohira M, Isogai $\mathrm{E}$, Kageyama $\mathrm{H}$, Imaizumi $\mathrm{M}$ and Nakagawara $\mathrm{A}$ : Bcl-2 is a key regulator for the retinoic acid induced apoptotic cell death in neuroblastoma. Oncogene 25: 5046-5055, 2006.

6. Bagatell R, Beck-Popovic M, London WB, Zhang Y, Pearson ADJ, Matthay KK, Monclair T, Ambros PF and Cohn SL: Significance of MYCN amplification in international neuroblastoma staging system stage 1 and 2 neuroblastoma: a report from the international neuroblastoma risk group database. J Clin Oncol 27: 365-370, 2009.

7. Ruth H, Minturn JE, Hishiki T, Zhao H, Wang Q, Cnaan A, Maris J, Evans AE and Brodeur GM: Proliferation of human neuroblastomas mediated by the epidermal growth factor receptor. Cancer Res 65 : 9868-9875, 2005.

8. Goillot E, Combaret V, Ladenstein R, Baubet D, Blay J-Y, Philip T and Favrot MC: Tumor necrosis factor as an autocrine growth factor for neuroblastoma. Cancer Res 52: 3194-3200, 1992.

9. Stupack DG, Teitz T, Potter MD, Mikolon D, Houghton PJ, Kidd VJ, Lahti JM and Cheresh DA: Potentiation of neuroblastoma metastasis by loss of caspase-8. Nature 439: 95-99, 2006.

10. Johnson E, Dean SM and Sondel PM: Antibody-based immunotherapy in high risk neuroblastoma (abstract). Expert Rev Mol Med 9: 1-21, 2007.

11. Simon T, Langler A, Harnischmacher U, Frühwald MC, Jorch N, Claviez A, Berthold F and Hero B: Topotecan, cyclophosphamide, and etoposide (TCE) in the treatment of high-risk neuroblastoma. Results of a phase-II trial. J Cancer Res Clin Oncol 133: 653-661, 2007.

12. Saulnier Sholler GL, Bergendahl GM, Genevieve M, Brard L, Singh AP, Heath BW, Bingham PM, Kamen AT, Barton A, Homans, AC, Slavik Marni A, Lenox SR, Higgins, TJ, Ferguson and William S: A phase 1 study of nifurtimox in patient with relapsed/refractory neuroblastoma. J Pediatr Hematol Oncol 33: 25-30, 2011.

13. Kutlik MT, Ayhan A, Gogus S, et al: Glutathione S-transferase and P-glycoprotein expressions in neuroblastoma J Pediatr Hematol Oncol 19: 337-345, 2002.

14. Cos P, De Bruyne T, Hermans N, Apers S, Berghe DV and Vlietinck AJ: Proanthocyanidins in health care: current and new trends. Curr Med Chem 11: 1345-1359, 2004.

15. Singh AP, Singh RK, Kim KK, Satyan KS, Nussbaum R, Torres M, Brard L and Vorsa N: Cranberry proanthocynidines are cytotoxic to human cancer cells and sensitize the platinum-resistant ovarian cancer cells to paraplatin. Phytother Res 23: 1066-1074, 2009. 
16. Koo H, Duarte S, Murata RM, Scott-Anne K, Gregoire S, Watson GE, Singh AP and Vorsa N: Influence of cranberry proanthocyanidins on formation of biofilms by streptococcus mutans on saliva-coated apatitic surface and on dental caries development in vivo. Caries Res 44: 116-126, 2010.

17. Singh RK, Lange TS, Kim KK, Singh AP, Vorsa N and Brard L: Isothiocyanate NB7M causes selective cytotoxicity, pro-apoptotic signaling and cell cycle regression in ovarian cancer cells. Br J Cancer 99: 1823-1831, 2008.

18. Kim KK, Lange TS, Singh RK and Brard L: Lipophilic aroylhydrazone chelator HNTMB and its multiple effects on ovarian cancer cells. BMC Cancer 10: 72, 2010.

19. Malich G, Markovic B and Winder C: The sensitivity and specificity of the MT tetrazolium assay for detecting the in vitro cytotoxicity of 20 chemicals using human cell lines. Toxicology 124: 179-192, 1997.

20. Petit PX, Lecoeur H, Zorn E, Dauguet C, Mignotte B and Gougeon M: Alterations in mitochondrial structure and function are early events of dexamethasone-induced thymocyte apoptosis. J Cell Biol 130: 157-167, 1995.

21. Huang R, Wallqvist A and Covell DG: Anti-cancer metal compounds in NCI's tumor-screening database: putative mode of action. Biochem Pharmacol 69: 1009-1039, 2005.

22. Chen KC and Chang LS: Arachidonic acid-induced apoptosis of human neuroblastoma SK-N-SH cells is mediated through mitochondrial alteration elicited by $\mathrm{ROS}$ and $\mathrm{Ca}(2+)$-evoked activation of p38alpha MAPK and JNK1. Toxicology 262: 199-206, 2009.

23. Johnsen JI, Segerström L, Orrego A, Elfman L, Henriksson M, Kågedal B, Eksborg S, Sveinbjörnsson B and Kogner P: Inhibitors of mammalian target of rapamycin downregulate $\mathrm{MYCN}$ protein expression and inhibit neuroblastoma growth in vitro and in vivo. Oncogene 27: 2910-2922, 2008.

24. Gómez-Santos C, Francisco R, Giménez-Xavier P and Ambrosio S: Dopamine induces TNF(alpha) and TNF-R1 expression in SH-SY5Y human neuroblastoma cells. Neuroreport 18: 1725-1728, 2007.

25. Guthrie N: Effect of cranberry juice and products on human breast cancer cell growth. FASEB J 14: A771, 2000.

26. Sreeam NP, Adams LS, Hardy ML and Heber D: Total cranberry extract versus its phytochemical constituents: anti-proliferative and synergistic effects against human tumor cell lines. J Agric Food Chem 52: 2512-2517, 2004

27. Neto CC: Cranberry and its phytochemicals: a review of in vitro anticancer studies. J Nutr 137: S186-S193, 2007.

28. Acosta S, Lavarino C, Paris R, Garcia I,De Torres C, Rodríguez E, Beleta $\mathrm{H}$ and Mora J: Comprehensive characterization of neuroblastoma cell line subtypes reveals bilineage potential similar to neural crest stem cells. BMC Develop Biol 9: 12, 2009.

29. Ross RA, Hein AM, Braca JA, Spengler BA, Biedler JL and Scammel JG: Glucocorticoids induce neuroendocrine cell differentiation and increase expression of $\mathrm{N}$-myc in N-type human neuroblastoma cells. Oncol Res 13: 87-94, 2002.

30. Ross RA, Spengler BA and Biedler JL: Coordinate morphological and biochemical interconversion of human neuroblastoma cells. J Natl Cancer Inst 71: 741-747, 1983.

31. Reynolds CP and Perez-Polo JR: Induction of neurite outgrowth in the IMR-32 human neuroblastoma cell line by nerve growth factor. J Neurosci Res 6: 319-325, 1981.

32. Rebbaa A, Chou PM, Emran M and Mirkin BL: Doxorubicininduced apoptosis in caspase-8-deficient neuroblastoma cells is mediated through direct action on mitochondria. Cancer Chemother Pharmacol 48: 423-428, 2001.

33. Johnsen JI, Pettersen I, Ponthan F, Sveinbjørnsson B, Flaegstad T and Kogner P: Synergistic induction of apoptosis in neuroblastoma cells using a combination of cytostatic drugs with interferongamma and TRAIL. Int J Oncol 25: 1849-1857, 2004.
34. Hettmer S, McCarter R, Ladisch S and Kaucic K: Alterations in neuroblastoma ganglioside synthesis by induction of GD1b synthase by retinoic acid. Br J Cancer 91: 389-397, 2004.

35. Lange TS, Kim KK, Singh RK, Strongin RM, McCourt CK and Brard L: Iron(III) salophene: an metallo-organic compound with selective cytotoxic and anti proliferative properties in platinumresistant ovarian cancer cells. PLOS One 3: e2303, 2008.

36. Li Z, Tan F, Liewehr DJ, Steinberg SM and Thiele CJ: In vitro and in vivo inhibition of neuroblastoma tumor cell growth by AKT inhibitor perifosine. J Natl Cancer Inst 102: 758-770, 2010

37. Evans AE, Kisselbach KD, Yamashiro DJ, Ikegaki N, Camoratto AM, Dionne CA and Brodeur GM: Antitumor activity of CEP-751 (KT-6587) on human neuroblastoma and medulloblastoma xenografts. Clin Cancer Res 5: 3594-3602, 1999.

38. Lestini BJ, Goldsmith KC, Fluchel MN, Liu X, Chen NL, Goyal B, Pawel BR and Hogarty MD: Mcll downregulation sensitizes neuroblastoma to cytotoxic chemotherapy and small molecule Bcl-2-family antagonists. Cancer Biol Ther 8: 1587-1595, 2009.

39. Wang S and El-Deiry WS: TRAIL and apoptosis induction by TNF-family death receptors. Oncogene 22: 8628-8633, 2003

40. Beltinger C,Fulda S, Walczak H and Debatin KM: TRAIL enhances thymidine kinase/ganciclovir gene therapy of neuroblastoma cells. Cancer Gene Ther 9: 372-381, 2002.

41. Hopkins-Donaldson S, Bodmer JL, Bourloud KB, Brognara CB, Tschopp J and Gross N: Loss of caspase-8 expression in highly malignant human neuroblastoma cells correlates with resistance to tumor necrosis factor-related apoptosis-inducing ligand induced apoptosis. Cancer Res 60: 4315-4319. 2000.

42. Marengo B, Raffaghello L, Pistoia V, Cottalasso D, Pronzato MA, Marinari UM and Domenicotti C: Reactive oxygen species: Biological stimuli of neuroblastoma cell response. Cancer Lett 228: 111-116, 2005.

43. Waris G and Ahsan HJ: Reactive oxygen species: role in the development of cancer and various chronic conditions. Carcinogenesis 5: 1-8, 2006.

44. Hileman EO, Liu J, Albitar M, Keating MJ and Huang P: Intrinsic oxidative stress in cancer cells: a biochemical basis for therapeutic selectivity. Cancer Chemother Pharmacol 53: 209-219, 2004.

45. Kim WH, Lee JW, Gao B and Jung MH: Synergistic activation of JNK/SAPK induced by TNF-alpha and IFN-gamma: apoptosis of pancreatic beta cells via the p53 and ROS pathway. Cell Signal 17: 1516-1532, 2005.

46. Osone S, Hosoi H, Kuwahara Y, Matsumoto Y, Lehara T and Sugimoto T: Fenretinide induces sustained-activation of $\mathrm{JNK} / \mathrm{p} 38$ MAPK and apoptosis in a reactive oxygen speciesdependent manner in neuroblastoma cells. Int J Cancer 112: 219-224, 2004.

47. McGowan AT and Fox BW: A proposed mechanism of resistance to cyclophosphamide mustard in a Yoshida cell line in vitro. Cancer Chemother Pharmacol 17: 223-226, 1986.

48. Bart J, Groen HJ, Hendrikse NH, van der Graaf WT, Vaalburg W and De Vries EG: The blood-brain barrier and oncology: new insights into function and modulation. Cancer Treat Rev 26: 449-462, 2000

49. Doolittle ND, Abrey LE, Ferrari N, Hall WA, Laws ER, McLendon RE, Muldoon LL, Peereboom D, Peterson DR, Reynolds CP, Senter P and Neuwelt EA: Targeted delivery in primary and metastatic brain tumors: summary report of the seventh annual meeting of the Blood-Brain Barrier Disruption Consortium. Clin Cancer Res 8: 1702-1709, 2002.

50. Shapiro GI and Harper JW: Anti-cancer drug targets: cell-cycle and checkpoint control. J Clin Invest 104: 1645-1653, 1999.

51. Hartwell LH and Kastan MB. Cell-cycle control and cancer. Science 266: 1821-1828, 1994. 